\title{
THE APPLICATION OF MULTIFACTOR MODEL LITCAC IN THE ORGANIZATION OF ASSEMBLY WORK OF FLEXIBLE CORRUGATED STEEL STRUCTURES
}

\author{
Leszek Janusz ${ }^{1}$, Oleg Kapliński ${ }^{2}$
}

\author{
${ }^{1}$ ViaCon Polska Ltd., Przemyslowa 6, 64-130 Rydzyna,Poland.E-mail:leszek@viacon.pl \\ ${ }^{2}$ Dept of Civil, Architecture and Environmental Engineering, \\ Poznan University of Technology, 60-965 Poznan, Poland. E-mail: oleg.kaplinski@ikb.poznan.pl
}

Received 12 December 2005; accepted 15 September 2006

\begin{abstract}
Structural corrugated steel plate structures (SCSPS) are the subject of this paper. Some aspects of assembly of these structures are discussed, indicating factors of organization. The considerations are based on the estimation of labour consumption. On the grounds of regression and correlation one can create a new model of labour consumption and total costs of assembly work. This model is called LITCAC and constitutes "an open" type model. It is for estimating labour consumption, time and cost of assembly of CSPS in four modules. A combination of the new proposed model with the method of multi-criteria optimization (in this case TOPSIS method) enables to improve the organization of predicting the job site progress as well as the cost related to site activities.
\end{abstract}

Keywords: corrugated steel structures, assembly process, modelling.

\section{Problem position}

The assembly of structural corrugated steel plate structures (CSPS) is the subject of this article. These structures are very often called flexible structures. They are useful in the construction of small bridges, culverts and pedestrian and vehicle underpasses. Considerations can be examined in two contexts: organization (in the estimation of labour consumption) and engineering (in the mechanization of work). Both contexts are identically important.

Context I: With the evolution of the technology the assembly techniques of CSPS have been gradually improving. The improvements were related either to organizational schemes on job site, assembly techniques, or equipment used on the job site. Experience from the job sites led to the development of various assembly models related to labour consumption. Most of them were rather primitive and simple and were based on deterministic assumptions. They are "closed" type models as they fixed the amount and quality of resources used in the assembly process thus not addressing a multi-factor interaction of variables taking part in the process. Detailed analyses of existing (15) models are presented by L. Janusz in [1]. Models proceeded from Europe, America and Australia. The results of the existing models were numbers of man-hours needed to assembly a structure of specific weight. The analysis of these results shows that except RS Means model other models underestimate labour consumption. The explanation to that lies in much lower efficiency of assembly reported during research than the efficiency assumed in the existing models. In this case $R M$ Means model presents the results based on Polish Catalogs KNR 2-33.

Context II: Assembly technique of CSPS has unique character which means that it requires the use of manpower and application of simple hand tools and machines (small cranes, often pay-loaders and excavators). An example of assembly of CSPS with final result is presented in Fig 1.

The investigation of the assembly process allowed symbolic description of the sub-processes that occur during installation. The recognized sub-processes are called primary processes and consist of:

1) internal transport of plates on the job site,

2) mounting of plates to shape the steel barrel,

3) bolting of the plates together by means of bolts,

4) torque of the bolts to required torque moment.

For these processes it was possible to determine five factors affecting assembly (c.f., Fig 2). Factors included in 


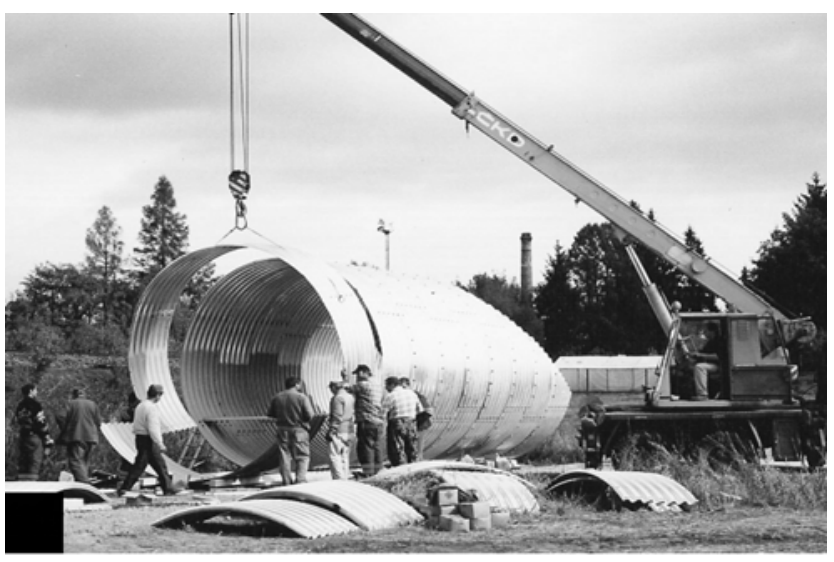

a)

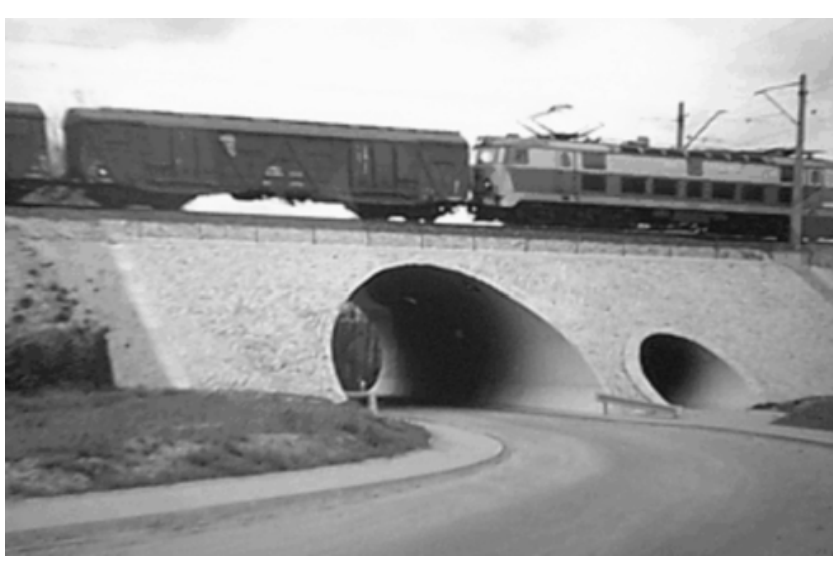

b)

Fig 1. CSPS structures: (a) assembly process in place; (b) one of the example of a finished structure

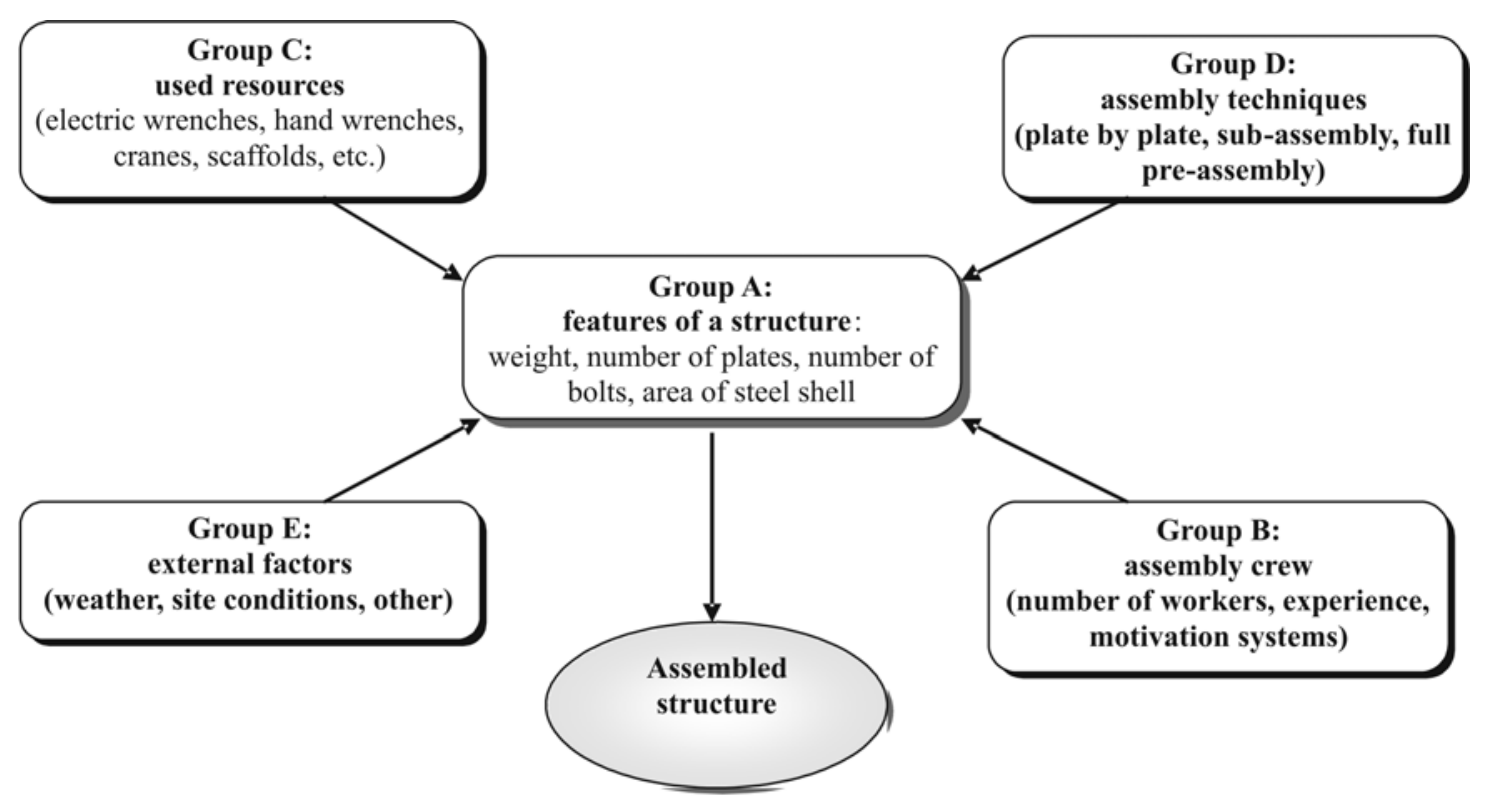

Fig 2. Division and action of factors

groups B, C, D, E act on factors from group A resulting in assembled structures. Groups B, C, D contain factors that can be changed by a contractor. Factors belonging to group A are fixed for a specific case and factors belonging to group $\mathrm{E}$ are beyond the power of a contractor, they are entirely independent and can't be controlled.

\section{Research}

The research method was chronometric measurement of the duration of identified assembly processes. The research was carried out from 1996 to 2002 mainly in Poland, but some data originated from Sweden, Ukraine and Czech Republic. These CSPS are manufactured by ViaCon Group [2]. The test set consisted of randomly chosen installation cases satisfying statistical rules of representation for general population.
The test set consisted of 148 cases of assembled CSPS with various shapes, geometry and weight. All structures had corrugation of $150 \times 50 \mathrm{~mm}$. The test set has been considered as statistically significant.

The obtained results were recorded on assembly cards and later on grouped into aggregated data spread sheet. Based on statistical analysis of the obtained results a number of key process factors and values were obtained, which were used for the construction of a new model.

\section{Proposal of a new model}

One can create a new model of labour consumption and total cost of assembly work on the grounds of regression and correlation.

This model is called LITCAC - Labour consumption, Time and Cost of Assembly of flexible Culverts. This model 


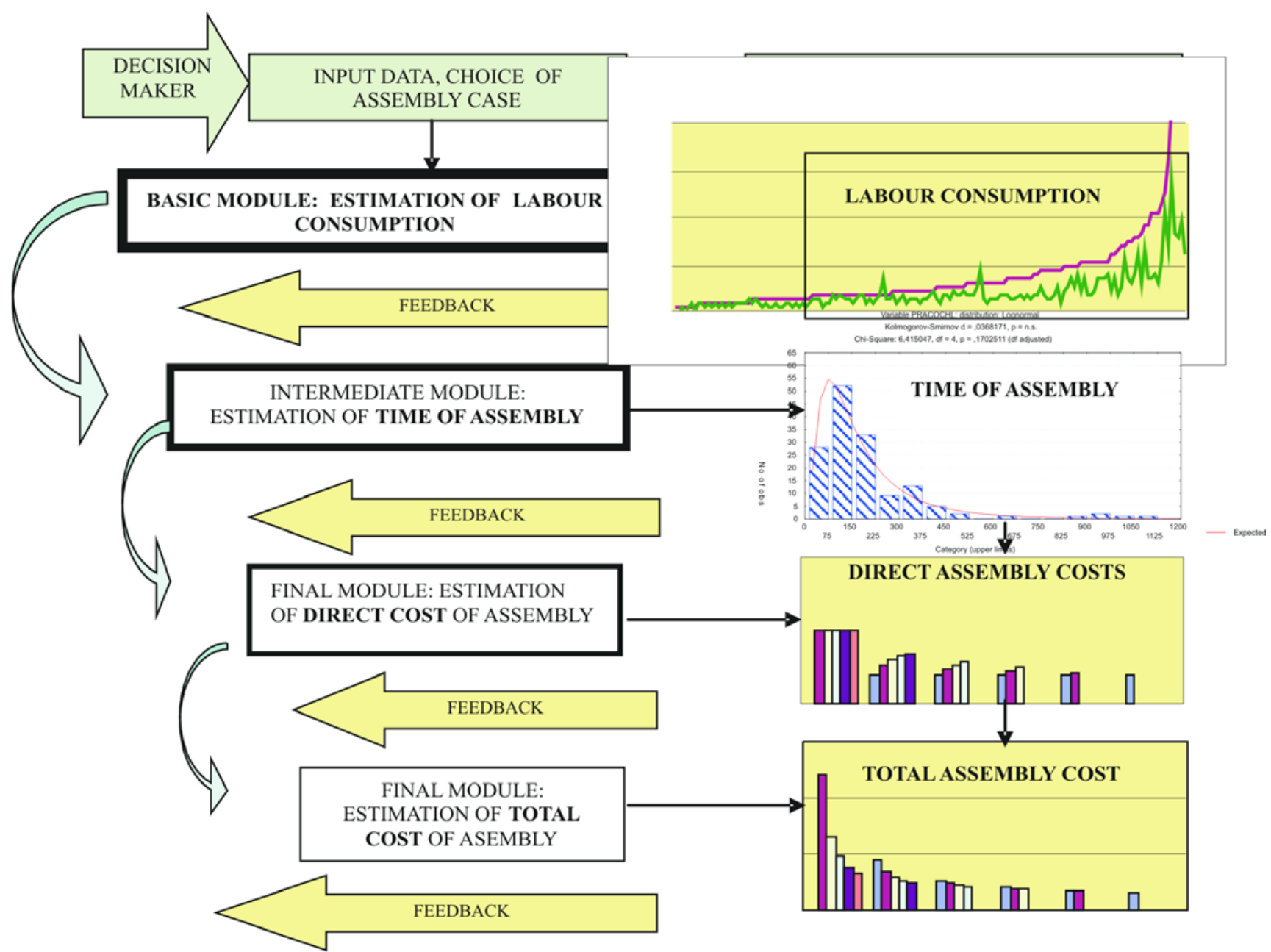

Fig 3. Four basic modules of LITCAC model

is an open type, which means that it allows for change of many of input parameters and follows the results of the change on labour consumption. Based on it one can estimate the cost of assembly introducing specific figures for cost items i.e. labour cost, machinery, overall daily cost etc. As a subsection the model provides a module for estimation of time of assembly counted in days (or shifts). Four basic modules of this model are presented in Fig 3. Whereas, four main equations of LITCAC model (after aggregation) are presented in Table 1, where:

$\mathrm{W}$ - weight of structure,

$c_{i}-$ cost of labour or equipment,

$n_{i}-$ number of assembly crew $\left(n_{3}\right)$, hand tools $\left(n_{1}\right)$, mechanical tools $\left(n_{2}\right)$ or cranes $\left(n_{4}\right)$,

$\alpha_{i}$-mechanization of bolting and torque increase index,

$\beta_{i}-$ mechanization of mounting steel plates increase index,

$\delta_{k}$-efficiency of hand torque and bolting,

$\delta_{r}$-efficiency of on site transportation and mounting of plates,

$\kappa-$ an index of relative cost of the use of heavy equipment versus the use of manpower in mounting of plates, $\kappa=c_{3} / c_{1}$, $c_{2}$ - cost of using mechanized wrenches,

$c_{3}-$ cost of using mechanized equipment for lifting and transporting of steel plates,

$\sigma-$ an index of relative cost of the use of mechanical wrenches versus the use of hand-tools in torque of bolts, $\sigma=c_{2} / c_{1}$,

$\xi_{\mathrm{i}}-$ corrective indices accounting for parallel processes occurrence.

For example, indices of the increase of output due to mechanization for "pipe-arch" structure are the following:

$\alpha_{i}=2,75$,

$\beta_{\mathrm{i}}=26,21$.

The results of statistical analysis efficiency factors for identified processes have been specified. They are presented in [1] and [3].

\section{Verification and application of the model}

Verification of the model has been performed based on the comparison with the results of a regression model and a simplified model, which is related to hourly output, as well as to the results of analysis with the use of artificial neural networks (ANN) [4]. 
Aggregated equations of LITCAC model

Labour consumption of assembly:

$\mathrm{L}=\left\{\mathrm{W} *\left(\mathrm{n}_{1}+\mathrm{n}_{2}\right) /\left[\left(\delta_{\mathrm{k}} *\left(\mathrm{n}_{1}+\mathrm{n}_{2} * \alpha_{\mathrm{i}}\right)+\mathrm{W} * \mathrm{n}_{3} * \xi_{3} /\left(\delta_{\mathrm{r}} *\left(\mathrm{n}_{3}+\mathrm{n}_{4} * \beta_{\mathrm{i}}\right)\right]\right\} * \xi_{\mathrm{i}}\right.\right.$

Time of assembly:

$$
\mathrm{T}=\left\{\mathrm{C} /\left[\delta_{\mathrm{k}} *\left(\mathrm{n}_{1}+\mathrm{n}_{2} * \alpha_{\mathrm{i}}\right)\right]+\mathrm{W} * \xi_{3} /\left(\delta_{\mathrm{r}} *\left(\mathrm{n}_{3}+\mathrm{n}_{4} * \beta_{\mathrm{i}}\right)\right]\right\} * \xi_{\mathrm{i}}
$$

Direct cost of assembly:

$$
\mathrm{C}_{\text {direct }}=\mathrm{W}^{*} \mathrm{c}_{1} * \xi_{\mathrm{i}} *\left\{\left[\mathrm{n}_{1}+\mathrm{n}_{2} *(1+\sigma)\right] /\left[\delta_{\mathrm{k}} *\left(\mathrm{n}_{1}+\mathrm{n}_{2} * \alpha_{\mathrm{i}}\right)\right]+\xi_{3} *\left(\mathrm{n}_{3}+\mathrm{n}_{4} * \mathrm{~K}\right) /\left[\delta_{\mathrm{r}} *\left(\mathrm{n}_{3}+\mathrm{n}_{4} * \beta_{\mathrm{i}}\right)\right]\right\}
$$

Total cost of assembly including overheads and general construction daily cost:

$$
\begin{gathered}
\mathrm{C}_{\text {total }}=\mathrm{W} * \mathrm{c}_{1} * \xi_{\mathrm{i}} *\left\{\left[\mathrm{n}_{1}+\mathrm{n}_{2} *(1+\sigma)\right] /\left[\delta_{\mathrm{k}} *\left(\mathrm{n}_{1}+\mathrm{n}_{2} * \alpha_{\mathrm{i}}\right)\right]+\xi_{3} *\left(\mathrm{n}_{3}+\mathrm{n}_{4} * \mathrm{\kappa}\right) /\left[\delta_{\mathrm{r}} *\left(\mathrm{n}_{3}+\mathrm{n}_{4} * \beta_{\mathrm{i}}\right)\right]\right\}+\left(\mathrm{c}_{\mathrm{o}} / \mathrm{r}\right) *\left\{\mathrm{~W} /\left[\delta_{\mathrm{k}} *\left(\mathrm{n}_{1}+\mathrm{n}_{2} * \alpha_{\mathrm{i}}\right)\right]+\right. \\
\left.+\mathrm{W}^{*} \xi_{3} /\left[\delta_{\mathrm{r}} *\left(\mathrm{n}_{3}+\mathrm{n}_{4} * \beta_{\mathrm{i}}\right)\right]\right\} * \xi_{\mathrm{i}}
\end{gathered}
$$

An average relative error for the analyzed test sub-set (pipe-arch type) obtained from LITCAC model as well as its dispersion was the lowest of the compared models.

The average relative error of prediction $(\varepsilon)$ for LITCAC model was $\varepsilon=0,44 \%$ with $\delta=22,40 \%$ (standard deviation), whereas ANN resulted in $\varepsilon=15,42 \%$ and $\delta=71,57 \%$ and regression model resulted in $\varepsilon=15,53 \%$ and $\delta=58,49 \%$.

The organization of assembly work is very dependant on setting the ultimate goal for the crew. One can choose between: minimum direct cost of assembly, minimum time of assembly, minimum labour consumption, maximum mechanization, etc. A suitable tool for multi-criteria optimization is a method called TOPSIS. This method belongs to multi-criteria decisionmaking support methods and is widely described by E. K. Zavadskas et al. [5], [6], and [7].

A practical example bases on the following problem: choosing solution for assuring the quality (and organization) of assembled CSPS at optimal cost. The minimum requirement for the organization of the assembled CSPS is a need to achieve torque of $240 \mathrm{Nm}$, which requires the use of minimum one electric wrench. CSPS weights $\mathrm{W}=30000 \mathrm{~kg}$.

Besides:

- unit labour $\operatorname{cost} c_{1}=12 \mathrm{USD} / \mathrm{man}-\mathrm{h}$;

- unit cost for using an electric wrench $c_{2}=$ $10 \mathrm{USD} / \mathrm{man}-\mathrm{h}$;

- unit cost of using a crane $c_{3}=200 \mathrm{USD} / \mathrm{machine-h}$;

- daily overhead costs for job site $c_{\mathrm{o}}=2000 \mathrm{USD} / \mathrm{shift}$.

A decision maker has three possibilities of resources at his discretion. The structure will be assembled in a country with little experience in the assembly of CSPS.

A decision maker (in this case - an operator) seeking the optimal solution considers three alternatives $\mathrm{A}_{1}, \mathrm{~A}_{2}$ and $\mathrm{A}_{3}$ which contain: an assembly crew (from 2 to 8 men), using 2 or 4 electric wrenches, hand keys (from 0 to 5), a number of cranes (0 or 1$)$.

A decision maker (operator) considers 4 criteria $\mathrm{K}_{1}-$ $\mathrm{K}_{4}$ : the lowest labour consumption, the shortest time of assembly, the lowest direct assembly cost, and the lowest total assembly cost, at the weight ranked from $w_{1}=0,1$ to $w_{4}=0,4$.

Based on LITCAC model values for 3 alternatives (A) set at 4 criteria $(\mathrm{K})$ have been determined. Having obtained the results from LITCAC model for set variables (resources and means) specified by crew composition $\left(\mathrm{A}_{1}-\mathrm{A}_{3}\right)$ we can start to seek an optimal solution at the given criteria. The results have been obtained by TOPSIS method [7]. A preference chain can be described as below:

$$
A_{2}>A_{1}>A_{3} \text {. }
$$

It means that for the set criteria mentioned above and assumptions for TOPSIS method in combination of the results obtained from LITCAC model option $\mathrm{A}_{2}$ gives the optimal solution in respect of goal function. Alternative $A_{2}$ refers: 4 men in an assembly crew, 4 electric wrenches, without hand keys and using one crane.

\section{Conclusions}

1. The presented LITCAC model addresses properly combined action of factors occurring in an assembly process of CSPS and therefore constitutes an open and interactive model.

2. A combination of a new developed model for estimating labour consumption, time and cost of the assembly of CSPS with the method for multi-criteria optimization in decision-making enables to improve the organization of predicting the job site progress as well as the cost related to site activities.

3. The analysis of the results from LITCAC model and TOPSIS method may indicate that optimal solutions can vary from country to country based on different economical constraints. 


\section{References}

1. Janusz, L. Multi-factor modelling of labour consumption and costs of assembly of corrugated steel structures (Wieloczynnikowe modelowanie pra-cochlonnosci i kosztow montazu konstrukcji z blach falistych), PhD. Thesis, Poznan University of Technology, Poznan, 2004 (in Polish).

2. Viacon. http://www.viacon.pl/indexok.html

3. Janusz, L. Research of labour consumption of assembly of corrugated steel structures with corrugation $150 \times 50$ and $380 \times 140$. Scientific Journal of The Higher Officer's School of Continental Armies, Wroclaw, 2003, p. 175-186 (in Polish).

4. Bień, J. Modelling of bridge structures in service process (Modelowanie obiektow mostowych w procesie ich eksploatacji), Wroclaw University of Technology Press, Wrocław, 2002. 348 p. (in Polish).

5. Zavadskas, E.; Kaklauskas, A. Automated multivariant design of buildings: Multipurpose comprehensive evaluation and selection of the most efficient version, Aalborg Universitetcenter, Aalborg, 1991. 65 p.

6. Zavadskas, E.; Pelschus, F.; Kaklauskas, A. Multiple criteria analysis of projects in construction. Vilnius: Technika, 1994.

7. Thiel, T. Methodical aspects of multi-criteria decision making in construction production engineering (Metodyczne aspekty wielokryterialnego podejmowania decyzji w inzynierii produkcji budowlanej), Ph. D. Thesis, Poznan University of Technology, Poznan, 1996 (in Polish).

\section{DAUGIAFAKTORIO LITCAC MODELIO TAIKYMAS RIFLIUOTŲJŲ LAKŠTINIŲ METALINIŲ KONSTRUKCIJŲ MONTAVIMO DARBAMS ORGANIZUOTI}

\section{Janusz, O. Kapliński}

\section{Santrauka}

Nagrinėjami kai kurie rifliuotujų lakštinių metalinių konstrukcijų montavimo organizavimo aspektai, ịvertinant darbo sąnaudas. Taikant regresinę ir koreliacinę analizę, sukurtas modelis montavimo darbų sąnaudoms ir išlaidoms nustatyti. Šis modelis pavadintas LITCAC ir yra priskiriamas ,atvirujų“" modelių klasei. Šis modelis sudarytas iš keturių modulių, skirtas metalinių konstrukcijų montavimo darbo sąnaudoms, trukmei ir kainai nustatyti. Pasiūlytojo modelio ir daugiakriterinès optimizacijos metodo (TOPSIS) integracija leidžia tiksliau suplanuoti darbus statybos aikšteleje bei nustatyti sąnaudas.

Raktažodžiai: rifliuotosios lakštinès metalinès konstrukcijos, montavimo procesas, modeliavimas.

Leszek JANUSZ. Director and president of managing board of ViaCon-Polska Ltd. He received his Ph. D. degree in Civil Engineering from Poznań University of Technology. Author and co-author of 35 papers. Research interests: bridges; structures, production and construction of flexible corrugated steel structures; management.

Oleg KAPLIŃSKI. Professor, Dr. Habil., Eng. Head of the Chair of Construction Engineering and Management at PUT. Author and co-author of 160 papers, articles and books. Member of Ukrainian Building Academy. Doctor honoris causa of Vilnius Gediminas Technical University. Member of Civil Engineering Committee of Polish Academy of Science and Chairman of the Section of Construction Management in this Committee. Research interests: organization and modelling of construction processes. 